Article

\title{
Occurrence and Risk of Metal(loid)s in Thelesperma megapotamicum Tea Plant
}

\author{
Christine Samuel-Nakamura ${ }^{1, *}$ and Felicia S. Hodge ${ }^{2,3}$ \\ 1 School of Nursing, University of California, Los Angeles (UCLA), 4-246 Factor Bldg., Mailcode 691821, \\ Los Angeles, CA 90095, USA \\ 2 School of Public Health, UCLA, 5-940 Factor Bldg., Mailcode 691921, Los Angeles, CA 90095, USA; \\ fhodge@sonnet.ucla.edu \\ 3 School of Nursing, UCLA, 5-940 Factor Bldg., Mailcode 691921, Los Angeles, CA 90095, USA \\ * Correspondence: csamnak@ucla.edu; Tel.: +1-310-206-8328
}

Received: 2 November 2019; Accepted: 29 November 2019; Published: 23 December 2019

check for updates

\begin{abstract}
This study reports on the harvesting, ingestion, and contamination of American Indian tea Thelesperma megapotamicum grown on the Navajo Reservation in New Mexico. Uranium (U) and co-metal(loid)s (As, Cd, Cs, Mo, Pb, Se, Th, and V) have contaminated local soil and plants. Tea plants were gathered for analysis near $U$ mining impacted areas. The study collected samples of wild tea plants $(n=14)$, roots $(n=14)$, and soil $(n=12)$ that were analyzed with inductively coupled plasma mass spectrometry. Tea harvesting activities, behavior, and ingestion information were collected via questionnaires. Harvesting took place in community fields and near roadways. Results indicate edible foliage concentration levels for $\mathrm{Cd}$ exceeded the World Health Organization (WHO) raw medicinal plant permissible level guidelines. Tea samples collected near high traffic areas had significantly greater $\mathrm{Cd}$ and Mo concentrations than those collected near low traffic areas $(p<0.001)$. Tea sample metal(loid) concentration levels ranged from $0.019-7.916 \mathrm{mg} / \mathrm{kg}$. When compared to established food guidelines including the WHO provisional tolerable weekly intake (PTWI), reference dietary intake, recommended dietary allowance, and the tolerable upper limit (UL), $\mathrm{Cd}$ exceeded the WHO guidelines but none exceeded the PTWI nor the UL. These findings warrant improved standardization and establishment of universal guidelines for metal(loid) intake in food.
\end{abstract}

Keywords: tea; uranium; cadmium; molybdenum; Navajo; Diné; provisional tolerable weekly intake; tolerable upper limit; metal(loid)s; greenthread

\section{Introduction}

Worldwide tea is one of the most popular beverages, second only to water [1]. The top growers and harvesters of herbal teas are India, Asia, the Middle East, and South America [2]. The benefits of herbal tea are touted by many for their medicinal, stress relieving, and antioxidant properties. Herbal tea has been shown to improve weight loss [3] and maintenance [4-6] as well as reduce the risk of diabetes onset $[5,6]$ and heart disease with resultant decreased low-density-lipoprotein cholesterol $[7,8]$. Moreover, many teas may possess antimicrobial [9] and anti-cancer effects [10,11].

American Indian (AI) Diné ethnobotanical uses of Thelesperma megapotamicum (Sprengel) Kuntze include its popular use as a beverage and diuretic, and its use as an agent to improve hematuria, pelvic pain, bladder stones, anuria [12], and indigestion [13]. The plant has several cultural uses including as a dye for wood, wool, and textiles (producing orange yellow or gold hues) [13]. Vernacular names include greenthread, Hopi or Navajo tea, and cota. Several additional Thelesperma species exist, each with specific uses such as the treatment of dental pain, nervous stimulant (T. gracile) [14], tea substitute (T. longipes and T. trifidum), and wood dye (T. subnudum). The local Diné names for the tea 
plant are "c'îl dehî" ("wild mountain tea") [15] or "ch'il gohwééh" (plant coffee). T. megapotamicum species provide a significant portion of the food derived energy of the Diné diet [16] and serves as an important cultural resource. This plant species has a wide distribution and extends from the southwest plains of the United States to South America [17]. T. megapotamicum is utilized by many Indigenous and non-Indigenous communities in North and South America.

Herbal teas are popular, easily accessible, low-cost, and presumed to be safe. However, multiple studies have documented toxicity, adverse events, untoward side effects, reactions (such as overdose, tolerance, and dependence and/or addiction), hypersensitivity and allergic reactions, and mid to long-term effects on multiple organ systems (including the heart, nervous, liver, and renal systems), genotoxicity, and teratogenicity $[18,19]$. Traditional communities are known to rely on herbal plants for medicinal and other cultural resources, but these natural harvest sites tend to be contaminated by anthropogenic activities [20]. The Navajo Reservation where the Diné people reside has been heavily impacted by $\mathrm{U}$ mining, which has resulted in more than 550 abandoned mines and waste sites. The $\mathrm{U}$ mining era occurred from the 1940s to the 1980s [21]. Hard rock mining areas are a problem in this and other AI communities with more than 160,000 mining sites existing [21] in the western U.S. Mining impacted areas on Diné lands have a potential to effect food resources as demonstrated by several reports on harvested herbs, forage plants, crops, meat, soil and water [22-24].

International tea studies abound $[19,25]$, however, few studies have examined AI tea harvesting, consumption, and uses. Even fewer studies have assessed AI tea harvested in environmentally contaminated mining areas where known contaminants were previously documented [23,26,27], with most plant studies primarily focusing on tea's biomacromolecular fractionation [28] and its antioxidant properties $[29,30]$.

Various contaminants in tea may pose health risks for those who consume it. Uranium is a renal chemical toxicant [31] and Cd is known to cause renal problems [32]. Lead causes neurodevelopmental problems [33]. Metalloids like As and Se are known teratogens [34,35], as are metals like Mo and Cs [36-38]. Thorium has been shown to cause cancer in high doses [39] and V can cause adverse respiratory effects [40]. Long-lasting and permanent deleterious health effects are common with metal(loids) such as $\mathrm{As}, \mathrm{Pb}, \mathrm{Cd}$, and Se. Many factors and exposure pathways exist and include plant species, the environment and soil, and plant stages of harvesting such as its location, collection, and its manner of preparation. Determining these factors and pathways are important in identifying ways to mitigate dietary exposure factors and risks.

This study determined the metal ( $\mathrm{Cd}, \mathrm{Cs}, \mathrm{Pb}, \mathrm{Mo}, \mathrm{T}, \mathrm{U}$, and $\mathrm{V}$ ) and metalloid (As and $\mathrm{Se}$ ) concentration levels in the tea plant, Thelesperma megapotamicum and soil sampled from within and near harvesting sites in known U mining impacted areas on Diné tribal lands in New Mexico (NM). The calculated human ingestion for the study cohort was reported in relation to the World Health Organization (WHO) raw medicinal plant permissible level (RMPPL); the provisional tolerable weekly intake (PTWI), the Food and Nutrition Board (FNB) reference dietary intake (RDI) or recommended dietary allowance (RDA), and tolerable upper limit (UL) for $\mathrm{As}, \mathrm{Cd}, \mathrm{Pb}, \mathrm{Mo}$, and Se. Notably, there are no established dietary guidelines for $\mathrm{Cs}$, Th, or $\mathrm{U}$. Based on a comparison between the WHO RMPPL and the PTWI guidelines, recommendations are presented.

\section{Materials and Methods}

\subsection{Setting}

Study samples were collected from August 1, 2012 to October 2, 2012 in a semi-arid region of the Navajo Reservation in northwestern NM (Figure 1). According to the monthly climatic meteorological data, the average precipitation is $25 \mathrm{~cm}$ per year [41]. The mean elevation is $2108 \mathrm{~m}$ (standard deviation $[\mathrm{SD}]=43$ ) and the mean temperature for the collection dates was $17.20 \pm 1.89^{\circ} \mathrm{C}$. Two "chapters" or communities, participated in the study, with their total, collective land mass being $764 \mathrm{~km}^{2}$ (individual land sizes were 531 and $233 \mathrm{~km}^{2}$ ). 


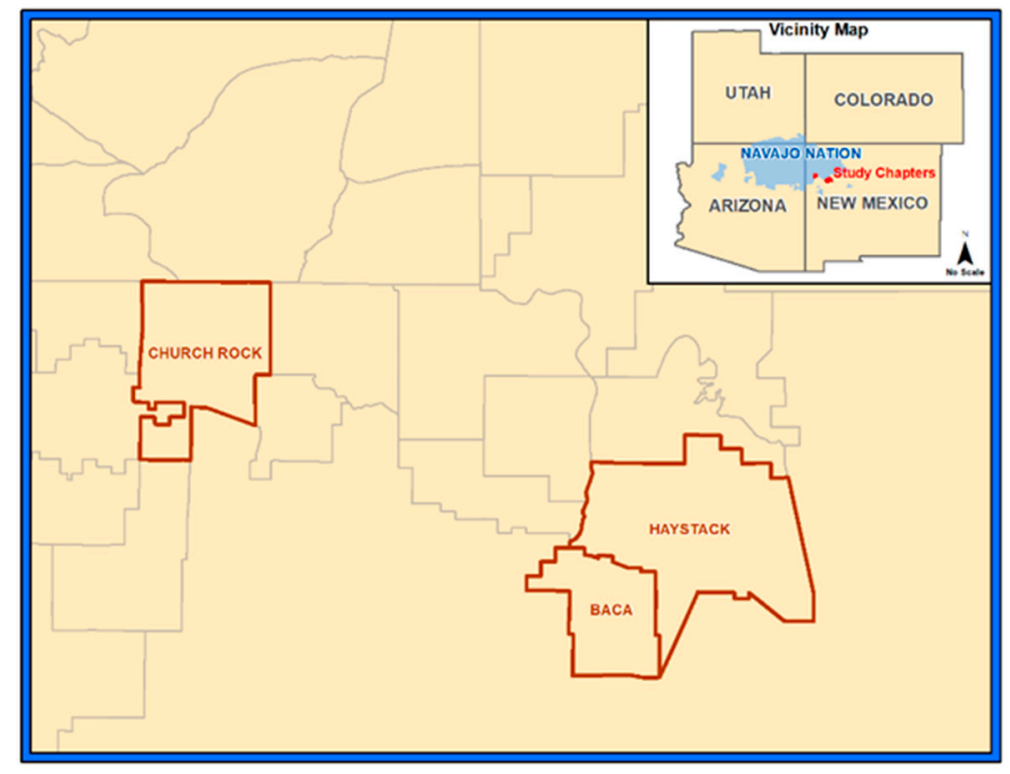

Figure 1. Participating chapters or communities (Churchrock and Baca/Haystack) on the Navajo Reservation in northwestern New Mexico. Inset shows their proximity to the Four Corners region of the USA.

Using a descriptive comparative design, samples of live T. megapotamicum plants coupled with soil samples were collected and their concentration of metals ( $\mathrm{U}, \mathrm{Cd}, \mathrm{Cs}, \mathrm{Pb}, \mathrm{Mo}$, Th, and $\mathrm{V})$ and metalloids (As, Se) were determined. Plant samples were collected near homes, in remote harvesting fields, and near local roadways.

The secured tribal community agreements permitted the administration of questionnaires and the collection of plants and soil specimens on reservation lands. Active consenting was conducted with a bilingual (Diné/English) language proficient researcher. The study was reviewed and approved by the University of California, Los Angeles (UCLA) Institutional Review Board (IRB\# 11-001594-CR-00005) and the Navajo Nation Human Research Review Board (\#NNR-11.321). T. megapotamicum is not listed as an endangered or threatened plant species according to the Navajo Nation Division of Natural Resources [42] or the state of NM Energy, Minerals, and Natural Resources Department [43].

Individuals recruited to participate were adult Diné residents of the included communities who were aged 18 years or older, not pregnant, were community residents for at least 10 years, and who harvested and consumed local foodstuffs. Participants recruited through flyers and meetings held at "Chapter Houses" (community meeting houses). Two questionnaires on harvesting practices, behavior, and dietary intake were administered to participating residents. Plant specimens were collected in the northwestern region of the Navajo Reservation where known contaminants were previously documented [26,27].

\subsection{Herbal Tea Samples}

Live tea samples were collected from wild, non-cultivated sources within a $3.2 \mathrm{~km}$ radius of the central part of abandoned $\mathrm{U}$ mines and features (mine portals, rim strips, pits, prospect areas, and vertical mine shafts). In addition, they were collected near vehicle roadways $<0.8 \mathrm{~km}$ from high traffic areas (HTAs) and $>2 \mathrm{~km}$ from low traffic areas (LTAs). The entire live plant (aboveground portions and roots) was stored in polyethylene (PE) plastic Ziplock ${ }^{\circledR}$ bags. The samples were weighed, photographed, bagged, and placed on dry ice for shipment for analysis by the Analytical Chemistry Laboratory Earth and Planetary Sciences Department at the University of New Mexico (UNM). The stems, leaves, flowers, and roots of T. megapotamicum were analyzed for metals $(\mathrm{Cd}, \mathrm{Cs}, \mathrm{Pb}, \mathrm{Mo}, \mathrm{T}$, $\mathrm{U}$, and $\mathrm{V}$ ) and metalloids (As, Se) using inductively coupled plasma-mass spectrometry (ICP-MS). 


\subsection{HTA and LTA Classifications}

Traffic data were classified according to the New Mexico Department of Transportation [44] functional classification system. The classification was categorized by traffic road volume, speed, and number of lanes, from Grade 1 having the highest traffic volumes, speed, and lanes and Grade 7 having the lowest traffic volumes, speed, and lanes. For the current study, the HTA tea samples were collected near traffic ways $<0.8 \mathrm{~km}$ and were classified as Grades 1 through 4 . The mean distance between HTA tea samples and the edge of busy roadways was $0.64 \mathrm{~km}(\mathrm{SD}=0.6$, range $0.58-0.71 \mathrm{~km})$. Tea samples from LTAs were collected $>2 \mathrm{~km}$ from roads that were classified as Grades 5 through 7 .

\subsection{Soil Samples}

Parallel soil samples were collected for each plant. A silicon-coated-core sampler (Art's Manufacturing and Supply Inc. (AMS), American Falls, ID, USA) was utilized to avoid cross contamination. A stainless-steel hand auger with a slide hammer was employed to collect soil samples using a PE liner (AMS Core Sampling Mini-kit, American Falls, ID, USA). One hundred grams (g) of soil were collected each from topsoil (0-15 cm depth) and root soil (5-25 cm depth). The soil samples were also analyzed for metal(loid)s (As, Cd, Cs, Pb, Mo, Se, Th, U, and V) using ICP-MS.

\subsection{Human PTWI Calculation Equations}

Human intake calculations were completed for $\mathrm{As}, \mathrm{Cd}$, and $\mathrm{Pb}[45,46]$ as follows:

PTWI $=$ daily intake of metals $=\sum$ [concentration of metals in tea $x$ mean of tea intake (grams per person per day)], weekly intake of metals = daily intake $\mathrm{x}$ seven days week; weekly intake per body weight $(\mathrm{kg})($ PTWIs) = weekly intake reference body weight $(60 \mathrm{~kg})$.

The number of grams per day of tea consumed $(5 \mathrm{~g})$ for this study was based on comparative data $[28,47]$.

\subsection{Plant Identification and Nomenclature}

Parallel live tea plant samples were collected and placed in a plant press until dry. They were identified and archived by the UNM Herbarium. The global positioning system (Trimble Navigation Limited, Westminster, CO, USA) was used to document the location of each plant, a description of the herb, and general county and state location information were collected.

\subsection{Sample Analysis}

Tea and environmental sample preparation and analysis have been reported in detail in previous publications [22-24]. Field samples were stored in a $-20^{\circ} \mathrm{C}$ freezer before sample preparation and analyses. The organic biota samples were oven dried at $65^{\circ} \mathrm{C}$. The plants were washed with 18 mega $\mathrm{Ohm}$ water then soaked in dilute $0.01 \mathrm{~N} \mathrm{HCl}$. The samples were prepared by weighing $2 \mathrm{~g}$ dry mass into the digestion tube. Two $\mathrm{mL}$ hydrogen peroxide $\left(\mathrm{H}_{2} \mathrm{O}_{2}\right)$ and $5 \mathrm{~mL}$ of ultra-high purity (UHP) nitric acid $\left(\mathrm{HNO}_{3}\right)$ were added and the solid samples (soil and plants) were gradually heated to $95^{\circ} \mathrm{C}$ and digested for two hours. The digested samples were transferred into $50 \mathrm{~mL}$ volumetric flasks and brought to volume using 18 mega Ohm water. Three $\mathrm{mL}$ of $\mathrm{HNO}_{3}$ (reagent blank) was run with each batch of samples. PerkinElmer NexION 300D ICP-MS (Waltham, MA, USA) was utilized to analyze the samples. The method detection limits are as follows: As $0.3 \mu \mathrm{g} / \mathrm{L}, \mathrm{Cd} 0.1 \mu \mathrm{g} / \mathrm{L}, \mathrm{Pb}, 0.008 \mu \mathrm{g} / \mathrm{L}$, Mo $0.02 \mu \mathrm{g} / \mathrm{L}$, Se $1.3 \mu \mathrm{g} / \mathrm{L}$, and U $0.008 \mu \mathrm{g} / \mathrm{L}$. Three replicates were measured for each sample. Certified reference materials were used and include the National Institute of Standards and Technology (NIST) Standard Reference Material (SRM) 1573a (Tomato Leaves, NIST Gaithersburg, MD, USA) and 2709 San Joaquin Soil (NIST, Gaithersburg, MD, USA) producing the following values for Cd and V: Cd: $1.474 \pm 0.11 \mathrm{mg} / \mathrm{kg}$ (certified reference tomato leaves: $1.52 \pm 0.04 \mathrm{mg} / \mathrm{kg}$ ) and $\mathrm{V}: 0.94 \pm 0.07 \mathrm{mg} / \mathrm{kg}$ (certified reference tomato leaves: $0.84 \pm 0.01 \mathrm{mg} / \mathrm{kg}$ ) and Cd: $0.64 \pm 0.09 \mathrm{mg} / \mathrm{kg}$ (certified reference 
soil value: $0.37 \pm 0.02 \mathrm{mg} / \mathrm{kg}$ ) and $\mathrm{V}: 83.2 \pm 7.7 \mathrm{mg} / \mathrm{kg}$ (certified reference soil value: $110 \pm 11 \mathrm{mg} / \mathrm{kg}$ ). Satisfactory precision results were found with relative SDs ranging from $7.3 \%$ to $13.8 \%$.

\subsection{Statistical Analysis}

Statistical Package for the Social Sciences (SPSS) for Windows (version 23, IBM, Armonk, NY, USA) was used for statistical analysis. Metal(loid) concentration levels in the tea and soil samples were reported as milligrams per kilogram $(\mathrm{mg} / \mathrm{kg})$. Summary data included means, standard deviations, medians, ranges, and percentages. Differences between metal(loid) levels in tea parts, soil, and HTA versus LTA were compared, with significance determined by the Student's $t$-tests. A $p$ value of $<0.05$ was considered significant. The absolute value of the $t$-statistic is reported, along with relevant means and/or interpretation of direction of difference.

\section{Results and Discussion}

\subsection{Human Tea Harvester Data}

All participating Diné tea harvesters were female. Their mean age was 61 years $(\mathrm{SD}=10.1$, range 43-78 years) and they had resided and utilized the local harvesting areas for a mean of 54 years $(\mathrm{SD}=5.67)$. On average, tea users included in the study ingested local T. megapotamicum tea 1.54 days per week for a mean of 35 years ( $S D=26$, range 6-58 years). All participants boiled dry and fresh tea, utilized all aboveground portions of the tea plant (leaf, stem, and flowers), and had utilized both young and mature plants. The tea was not mixed or combined with other herbs or substances except infusion water. Two-thirds of the harvesters reported rinsing tea herbs before boiling and ingestion. All participants shared the tea free of charge with people residing off and on the reservation. Only one participant reported selling the tea both on and off Diné lands. One third of the tea harvesters had previously utilized T. megapotamicum as a pigment to dye sheep wool textiles.

Food harvesting behavior was determined to identify and document the various pathways of exposure. Researchers were able to demonstrate that participants had lived near the harvesting areas for extensive periods of time ( $>5$ decades) and had consumed tea for more than three decades. Tea harvest areas were used by multiple generations. In most instances, the tea harvesting areas had existed and were used prior, during, and after the peak mining era. In examining tea preparation behavior, this cohort exclusively infused the aboveground portion of tea plant while excluding the root portion. This was a positive finding, the majority of the tea roots contained greater metal(loid) concentrations than their aboveground counterparts. One-third of participants also reported not rinsing the raw tea before preparation and ingestion. This is another potential route of exposure that has been identified and poses opportunities for behavioral modification. A study by Jing et al. [6] demonstrated that rinsing tea leaves with distilled water removed $44 \%$ of $\mathrm{Pb}$, which suggests a clear case for educational intervention. As with this study, food sharing behavior within the local community has been found to be extensive and common with other North AI communities [48]. The extent to which food is shared or sold with local harvesting communities bears further study, characterization, and provides educational opportunities.

\subsection{Metal(loid) Concentration Levels in Tea Plant Parts and Soil}

The majority of the aboveground portions of tea had less metal(loid) concentrations than the roots (Table 1). The metal(loid)s that met statistical significance were As $(\mathrm{t}(26)=4.84 ; p<0.05)$, $\mathrm{Cd}(\mathrm{t}(26)=1.47 ; p<0.05), \mathrm{Cs}(\mathrm{t}(26)=3.03 ; p<0.05), \mathrm{Mo}(\mathrm{t}(25)=1.64 ; p<0.05), \mathrm{Pb}(\mathrm{t}(26)=6.40$; $p<0.05), \mathrm{U}(\mathrm{t}(26)=8.20 ; p<0.05)$, and V ( $\mathrm{t}(26)=4.93 ; p<0.05)$. This finding is consistent with other international tea studies $[49,50]$. In fact, it was reported that the feeding roots (vs. main roots) acted as a buffer for aboveground plant part $\mathrm{Cd}$ and As uptake [50]. Other studies have reported that low $\mathrm{pH}$ (5.5-6.5) can facilitate $\mathrm{Cd}$ transfer and accumulation [51,52]. The current study $\mathrm{pH}$ was $6.5 \pm 0.6$, which may have been an important factor in this study. Other important variables affecting metal(loid) uptake 
reported in the literature include geology, atmosphere, climatic conditions [53], co-occurrence with other metal(loid)s, physicochemical properties of the soil, exposure period, dispersion range, and uptake ability of plant species $[20,54]$. The contamination may occur at various tea harvesting stages and includes the environment from which the plant was harvested, along with the collection, preparation, and processing of the plant [28], steeping or brewing conditions, storage [53], and transport [55]. It is beyond the scope of this paper to describe all the variables associated with metal(loid) uptake in detail.

Table 1. Metal(loid) concentrations in T. megapotamicum plant parts. Data expressed as mean \pm SD, reported in $\mathrm{mg} / \mathrm{kg}$.

\begin{tabular}{cccccc}
\hline Metal(loid)s & $\begin{array}{c}\text { Herb } \\
(\boldsymbol{n}=\mathbf{1 4})\end{array}$ & $\begin{array}{c}\text { Root } \\
(\boldsymbol{n}=\mathbf{1 4})\end{array}$ & $\begin{array}{c}\text { Root Soil } \\
(\boldsymbol{n}=\mathbf{2})\end{array}$ & $\begin{array}{c}\text { Topsoil } \\
(\boldsymbol{n}=\mathbf{1 2})\end{array}$ & $\begin{array}{c}\text { WHO RMPPL } \\
\mathbf{m g} / \mathbf{k g}\end{array}$ \\
\hline As & $0.423 \pm 0.103^{1,3}$ & $0.758 \pm 0.238^{1}$ & $2.315 \pm 1.168$ & $1.844 \pm 0.496^{3}$ & 1 \\
\hline Cd & $0.346 \pm 0.311^{1,3}$ & $0.634 \pm 0.658^{1}$ & $0.050 \pm 0.029$ & $0.512 \pm 0.228^{3}$ & 0.3 \\
\hline Cs & $0.063 \pm 0.074^{1,4}$ & $0.213 \pm 0.169^{1}$ & $0.488 \pm 0.264$ & $1.082 \pm 0.357^{4}$ & $-^{5}$ \\
\hline Pb & $0.304 \pm 0.731^{1,3}$ & $0.809 \pm 0.286^{1}$ & $5.783 \pm 3.704^{2}$ & $5.207 \pm 1.266^{2,3}$ & 10 \\
\hline Mo & $7.916 \pm 9.291^{1,4}$ & $18.304 \pm 21.563^{1}$ & nd & $10.562 \pm 5.232^{4}$ & $-^{5}$ \\
\hline Se & $0.738 \pm 0.393^{3}$ & $1.242 \pm 0.557^{5}$ & nd & $1.122 \pm 0.113^{3}$ & $-^{5}$ \\
\hline Th & $0.200 \pm 0.248^{5}$ & $0.268 \pm 0.163$ & $2.642 \pm 1.946$ & $2.940 \pm 0.815$ & $-^{5}$ \\
\hline $\mathbf{U}$ & $0.019 \pm 0.012^{1,3}$ & $0.114 \pm 0.041^{1}$ & $0.829 \pm 0.420$ & $1.290 \pm 0.224^{3}$ & $-^{5}$ \\
\hline $\mathbf{V}$ & $0.244 \pm 0.096^{1,4}$ & $2.343 \pm 1.589^{1}$ & $9.203 \pm 4.008$ & $16.297 \pm 5.7999^{4}$ & $-^{5}$ \\
\hline
\end{tabular}

Note: ${ }^{1}$ Aboveground herb compared to root, $p<0.05 ;{ }^{2}$ Root soil compared to topsoil, $p<0.05 ;{ }^{3}$ Tea herb compared to topsoil, $p<0.05 ;{ }^{4}$ Tea herb compared to topsoil, $p<0.001 ;{ }^{5}$ There are no established guidelines in the WHO RMPPL for Cs, Mo, Se, Th, U, or V; nd = not detected.

Topsoil metal(loid) concentration levels were greater than the root soil; although only $\mathrm{Pb}$ was found to be statistically significant $(p<0.05)$. Most metal(loid)s showed the following concentration distributions: root soil $>$ topsoil $>$ root $>$ herb. However, the concentration distributions for Mo and Se were in the order of root $>$ topsoil $>$ herb. The greatest concentration differences occurred in the aboveground portions compared to the root for Mo $(7.916 \mathrm{mg} / \mathrm{kg}$ vs. $18.304 \mathrm{mg} / \mathrm{kg})$ and V $(0.244 \mathrm{mg} / \mathrm{kg}$ vs. $2.343 \mathrm{mg} / \mathrm{kg}$ ), with each differing by one order of magnitude.

The overall $\mathrm{U}$ concentration levels were the lowest in all aboveground tea parts and root categories, except in root soil and topsoil (it was the third and fourth lowest in the latter categories). Generally, smaller U concentrations levels were demonstrated in squash crop, but greater metal(loid) concentrations ( $\mathrm{As}, \mathrm{Pb}, \mathrm{Se}$, and $\mathrm{U}$ ) were seen in seven species of aboveground sheep forage plants, root, and soil in the parent study [22,24].

International studies have examined diverse tea species and found varying metal(loid) concentration levels. First, the current study found greater concentration levels for $\mathrm{Cd}$, Mo, and V. Several studies have reported lower Cd concentrations in China (from below detection to $0.10 \mathrm{mg} / \mathrm{kg}$ ) $[50,56,57]$. The Mo concentration levels in this study were greater than in other tea studies $(0.04-4.2 \mathrm{mg} / \mathrm{kg}$ ) [58,59]. Antal et al. [60] found lower concentrations than what was detected with $\mathrm{V}$ concentrations of $0.031-76.3 \mathrm{mg} / \mathrm{kg}$ in tea aerial parts and $0.026-14.5 \mathrm{mg} / \mathrm{kg}$ in tea leaves. Equivocal concentration levels were found with studies examining $\mathrm{Cd}, \mathrm{Pb}$, and $\mathrm{Se}$ studies. A tea study in Turkey found comparable Cd concentrations in tea leaves $(0.05-1.27 \mathrm{mg} / \mathrm{kg})$ [61]. The study concentration ranges for $\mathrm{Pb}$ in China and the Middle East were of similar range to the current study $(0.30-3.42 \mathrm{mg} / \mathrm{kg})[56,62,63]$. Se concentrations fell between 1.12 to $2.26 \mathrm{mg} / \mathrm{kg}$ for Kolachi et al. [64] and from 0.096 to $0.114 \mathrm{mg} / \mathrm{kg}$ for Nookabkaew and associates [65]. Finally, several studies have determined and reported higher metalloid concentration levels for four metal(loid)s. The As concentration levels seen in our study were lower than those in Asia $(0.024-1.53 \mathrm{mg} / \mathrm{kg})[50,56,65]$, likewise Steenkamp et al. [66] reported higher ranges of $U$ concentrations at $10-60 \mathrm{mg} / \mathrm{kg}$ in African herbal samples from a $\mathrm{U}$ mining impacted area. Two recent studies reported greater Th concentration 
levels ranging from 0.597 to $9.918 \mathrm{mg} / \mathrm{kg}$ [67] and from 2.46 to $14.76 \mathrm{mg} / \mathrm{kg}$ [68]. Cesium radioactivity concentration levels were reported by Oprea et al. [68] and Mitrovic et al. [69], however, the current study did not determine radiological risk.

The current study found that the Cd concentration level $(0.35 \mathrm{mg} / \mathrm{kg})$ in this popular species of tea herb exceeded the WHO RMPPL of $0.3 \mathrm{mg} / \mathrm{kg}[45,70]$. Additionally, the WHO [71] recommends that medicinal plants used for various herbal formulations (teas, tinctures, etc.) should be evaluated for the presence of heavy metals [70]. The RMPPL of toxic metals are set at $1 \mathrm{mg} / \mathrm{kg}$ for As and $10 \mathrm{mg} / \mathrm{kg}$ for $\mathrm{Pb}[28,71]$.

\subsection{Metal(loid) Concentration Levels in HTAs and LTAs}

The mean distance between LTA T. megapotamicum samples was $6.01 \mathrm{~km}(\mathrm{SD}=4.40$, range: 2.12-11.55). In the majority of samples, HTA metal(loid) concentration levels were greater $(\mathrm{Cd}, \mathrm{Pb}$, Mo, Se, Th, U, and V, $p<0.001$ ) than those of LTAs (As and Cs, $p<0.05$ ). However, only five metals were found to be statistically significant: $\mathrm{Cd}(\mathrm{t}(12)=15.18 ; p<0.001)$, Mo (t $(111)=-4.70 ; p<0.001)$, $\mathrm{U}(\mathrm{t}(12)=0.74 ; p<0.05), \mathrm{V}(\mathrm{t}(12)=1.20 ; p<0.05)$, and Cs $(\mathrm{t}(12)=2.44 ; p<0.05$ (Table 2$)$.

Table 2. Metal(loid) concentrations in aboveground portions of T. megapotamicum from HTAs and LTAs. Data expressed as mean $\pm \mathrm{SD}$, reported in $\mathrm{mg} / \mathrm{kg}$.

\begin{tabular}{ccc}
\hline Metal(loid)s & $\begin{array}{c}\text { High Traffic Areas (HTAs) } \\
(\boldsymbol{n}=\mathbf{6})\end{array}$ & $\begin{array}{c}\text { Low Traffic Areas (LTAs) } \\
(\boldsymbol{n}=\mathbf{8})\end{array}$ \\
\hline $\mathrm{As}$ & $0.360 \pm 0.093$ & $0.470 \pm 0.086$ \\
\hline $\mathrm{Cd}$ & $0.681 \pm 0.106^{2}$ & $0.095 \pm 0.062^{2}$ \\
\hline $\mathrm{Cs}$ & $0.021 \pm 0.008^{1}$ & $0.095 \pm 0.085^{1}$ \\
\hline $\mathrm{Pb}$ & $0.320 \pm 0.030$ & $0.292 \pm 0.094$ \\
\hline $\mathrm{Mo}$ & $18.042 \pm 3.011^{2}$ & $0.321 \pm 0.171^{2}$ \\
\hline $\mathrm{Se}$ & $0.996 \pm 0.246$ & $0.544 \pm 0.379$ \\
\hline $\mathrm{Th}$ & $0.501 \pm 0.264$ & $0.087 \pm 0.121$ \\
\hline $\mathrm{U}$ & $0.029 \pm 0.013^{1}$ & $0.013 \pm 0.005^{1}$ \\
\hline $\mathrm{V}$ & $0.306 \pm 0.119^{1}$ & $0.198 \pm 0.035^{1}$ \\
\hline
\end{tabular}

Note: ${ }^{1}$ LTAs greater than HTAs, $p<0.05 ;{ }^{2}$ HTAs greater than LTAs, $p<0.001$.

Several studies found that tea collected closer to roadways contained significantly more contaminants [6,54,72]. More narrow distances (50-100 m) from HTAs also showed there were less contaminants associated with plants harvested for tea [72]. A comparison of the metal(loid) concentrations from this current study to the WHO RMPPL guidelines revealed unsafe levels of $\mathrm{Cd}$, as high as $226 \%$ above the guideline for samples from HTAs. Fortunately, the As and Pb levels did not exceed the WHO RPMML guidelines. Roadway contaminants are known to result from anthropogenic activities such as mining, re-suspended road dust, water run-off, vehicle part wear, tire wear, and vehicular emissions [72,73]. Furthermore, HTAs pose an increased risk of metal inhalation, ingestion, and dermal exposure according to Steenkamp et al. [66].

\subsection{Human PTWI Calculations}

The weekly intake calculations for T. megapotamicum tea were $0.25 \mu \mathrm{g} / \mathrm{kg}$ for As, $0.20 \mu \mathrm{g} / \mathrm{kg}$ for Cd, and $0.18 \mu \mathrm{g} / \mathrm{kg}$ for $\mathrm{Pb}$ (Table 3). The PTWI percentages for the aboveground portion of tea were all less than $3 \%$ (1.7\% for As, $2.9 \%$ for $\mathrm{Cd}$, and $0.7 \%$ for $\mathrm{Pb})$. The PTWIs for the current tea ingesting cohort were not exceeded. 
Table 3. Summary of dietary exposure to $\mathrm{As}, \mathrm{Cd}$, and $\mathrm{Pb}$ from the tea consumption of $5 \mathrm{~g}$, 1.54 days per week relative to PTWIs.

\begin{tabular}{cccc}
\hline Metal(loid)s * & $\begin{array}{c}\text { Weekly Intake } \\
(\mu \mathrm{g} / \mathbf{k g} \text { BW })\end{array}$ & $\begin{array}{c}\text { PTWI } \\
(\mu \mathrm{g} / \mathbf{k g} \text { BW })\end{array}$ & \% below PTWI \\
\hline $\mathrm{As}$ & 0.25 & 15 & 1.66 \\
\hline $\mathrm{Cd}$ & 0.20 & 7 & 2.85 \\
\hline $\mathrm{Pb}$ & 0.18 & 25 & 0.72 \\
\hline Note: * There is no PTWI for Cs, Mo, Se, Th, U, or V; BW = body weight.
\end{tabular}

In other parts of the world, the vast majority of tea studies did not exceed the PTWIs [28,49,74-76]. In some instances, the RMPPL or other guideline was used for reference. For example, Caldas and Machado's [33] examination of several medicinal herbs exceeded the WHO RMPPL for $\mathrm{Cd}$ and Pb, with $\mathrm{Pb}$ in horse chestnuts (Aesculus hippocastanum) exceeding the PTWI by $440 \%$ (Cd did not exceed the PTWI). Similarly, Han et al. [49] found that $\mathrm{Pb}$ exceeded the national maximum permissible concentration (MPC), but not the PTWI. In the first case, the researchers recommended stricter systematic control on the use of medicinal plants (particularly for A. hippocastanum). In the second case, the investigators reported both guidelines and concluded that the contribution to human $\mathrm{Pb}$ intake from drinking tea was small, but considerable at the highest concentration. Neither study discussed the discrepancy between the various guidelines.

\subsection{Human Intake Calculations for RDI or RDA and UL}

The daily intake calculations were $8.7 \mu \mathrm{g}$ for Mo, $0.8 \mu \mathrm{g}$ for Se, and $0.3 \mu \mathrm{g}$ for $\mathrm{V}$ (Table 4 ). The results showed that $19.4 \%$ of the RDA for Mo and $1.5 \%$ of the RDI for Se were consumed from tea. There is no established RDI or RDA for V [77]. The calculated intakes for V, Se, and Mo were all below the UL $(0.02 \%, 0.2 \%$, and $0.4 \%$, respectively). None of the ULs were exceeded for the listed metal(loid)s in any of the samples. Arsenic, Cd, Cs, Pb, Th, and U have no established RDIs, RDAs, or ULs.

Table 4. Summary of the dietary exposure to metal(loid)s from 1.54 days per week of tea consumption relative to the RDI or RDA and UL.

\begin{tabular}{|c|c|c|c|}
\hline Metal(loid)s * & $\begin{array}{l}\text { Daily Intake } \\
(\mu g)\end{array}$ & $\begin{array}{l}\text { RDI or RDA and UL } \\
(\mu \mathrm{g} / \text { day })\end{array}$ & $\begin{array}{c}\text { \% below RDI or RDA } \\
\text { and UL }\end{array}$ \\
\hline \multirow{2}{*}{ Mo } & \multirow{2}{*}{8.71} & RDA: 45 & 19.35 \\
\hline & & UL: 2000 & 0.44 \\
\hline \multirow{2}{*}{ Se } & \multirow{2}{*}{0.81} & RDI: 55 & 1.47 \\
\hline & & UL: 400 & 0.20 \\
\hline $\mathrm{V}$ & 0.27 & UL: 1800 & 0.02 \\
\hline
\end{tabular}

None of the FNB guidelines were exceeded in all categories. However, the micronutrients Mo and Se were below the required RDA and RDI, respectively. In this cohort, additional Se and Mo from foods may be necessary such as nuts, legumes (Mo) meats, and grains (Se). As such, the RDI and RDA requirements may have been met in this study sample by the combination of tea ingestion and other foods consumed, however, this study exclusively focused on one harvested food item of the entire diet. In the parent cohort, varying findings were found with Mo and Se whereby squash did not meet the Mo RDA and Se RDI [24]. However, both micronutrients were exceeded in sheep meat by 205\% (Mo RDA) and 713\% (Se RDI) [22]. It is advisable to consider all foods consumed collectively to avoid exceedances above the UL. The advisement of dietary intake from a health care provider or dietitian is recommended in similar settings. 


\subsection{Human PTWI Calculations for Samples from HTAs and LTAs}

The HTA and LTA weekly intake calculations were, respectively, 0.19 and $0.17 \mu \mathrm{g} / \mathrm{kg}$ for Pb, 0.21 and $0.27 \mu \mathrm{g} / \mathrm{kg}$ for As, and 0.40 and $0.06 \mu \mathrm{g} / \mathrm{kg}$ for Cd (Table 5). All were below $6 \%$ of the PTWI. With the exception of As, all the HTA percentages were greater than the LTA percentages. For Cd, the difference between HTAs and LTAs was one order of magnitude. When considering the PTWIs collectively from Table 3, the percentages were lower (0.7-2.8\%) than by a comparison of PTWI percentages by HTA and LTA (0.7-5.7\%; Table 5), particularly for Cd with the HTA greater by nearly 5\%. No recent literature has compared the PTWIs between HTAs and LTAs. However, Han et al. [63] completed a traffic study examining $\mathrm{Pb}$ concentration levels at incremental distances from the road from 0-200 m, however, the reported findings did not relate the distances to the calculated PTWIs.

Table 5. Summary of dietary exposure to $\mathrm{As}, \mathrm{Cd}$, and $\mathrm{Pb}$ from a $5 \mathrm{~g}$ intake of tea 1.54 days per week comparing the PTWIs of HTAs to LTAs.

\begin{tabular}{cccc}
\hline $\begin{array}{c}\text { Metal(loid)s in HTAs } \\
\text { and LTAs }\end{array}$ & $\begin{array}{c}\text { Weekly Intake } \\
\mu \mathrm{g} / \mathbf{k g ~ B W}\end{array}$ & $\begin{array}{c}\text { PTWI } \\
(\mu \mathrm{g} / \mathbf{k g ~ B W})\end{array}$ & \% Below PTWI \\
\hline HTA As & 0.21 & & 1.4 \\
\hline LTA As & 0.27 & 15 & 1.8 \\
\hline HTA Cd & 0.40 & & 5.71 \\
\hline LTA Cd & 0.06 & 7 & 0.86 \\
\hline HTA Pb & 0.19 & & 0.76 \\
\hline LTA Pb & 0.17 & 25 & 0.68 \\
\hline
\end{tabular}

\subsection{Human Intake Calculation Estimates for RDI or RDA and UL for Samples from HTAs and LTAs}

The daily intake calculations for HTAs and LTAs, respectively, were as follows: V was $0.3 \mu \mathrm{g}$ and $0.2 \mu \mathrm{g}$, Se was $1.1 \mu \mathrm{g}$ and $0.6 \mu \mathrm{g}$, and Mo $19.9 \mu \mathrm{g}$ and $0.4 \mu \mathrm{g}$ (Table 6). The differences in percentages between samples from HTAs and LTAs were greater for Mo and Se than V. The Mo RDA for HTA samples was $44 \%$ compared to $0.9 \%$ for the LTA samples. HTA samples contained $2.0 \%$ of the RDI for Se versus $1.1 \%$ for LTA samples. As indicated above, there are no established RDAs or RDIs for V. The calculated daily intakes for Mo, Se, and V were all below the ULs, ranging from $0.02 \%$ to $0.99 \%$ for HTA samples and from $0.01 \%$ to $0.2 \%$ for LTA samples.

Table 6. Summary of the dietary exposure to metal(loid)s from tea consumption representative of 1.54 days per week in comparison to the RDI or RDA, and UL in HTA and LTA.

\begin{tabular}{|c|c|c|c|}
\hline $\begin{array}{l}\text { Metal(loid)s in } \\
\text { HTAs and LTAs }\end{array}$ & $\begin{array}{l}\text { Daily Intake } \\
(\mu g)\end{array}$ & $\begin{array}{l}\text { RDI or RDA and } \\
\text { UL ( } \mu \mathrm{g} / \text { day) }\end{array}$ & $\begin{array}{c}\text { \% below RDI or RDA } \\
\text { and UL }\end{array}$ \\
\hline HTA Mo & 19.85 & \multirow{2}{*}{ RDA: 45; UL: 2000} & $44.1 ; 0.99$ \\
\hline LTA Mo & 0.4 & & $0.88 ; 0.02$ \\
\hline HTA Se & 1.10 & \multirow{2}{*}{ RDI: 55; UL: 400} & $2.0 ; 0.3$ \\
\hline LTA Se & 0.61 & & $1.11 ; 0.15$ \\
\hline HTA V & 0.34 & \multirow{2}{*}{ UL: 1800} & 0.02 \\
\hline LTA V & 0.22 & & 0.01 \\
\hline
\end{tabular}

Mo had a difference between HTA and LTA samples of two orders of magnitude and reflectively the RDA for HTA was a large percentage higher (about 43\%). Consuming tea from HTAs to meet the RDA for Mo is not recommended. Mo has a very limited number of studies focused on tea [70] and needs further characterization and research. Similar to the collective calculation of RDI or RDA and ULs, the HTA and LTA findings were below all guideline categories. 


\subsection{Differences between the WHO RMPPL and the PTWI Guidelines}

T. megapotamicum tea and soil were examined and the human implications were examined by calculating the PTWI, RDA, or RDI and ULs. There were notably large differences found between whether or not $\mathrm{Cd}$ exceeded the threshold based on whether the WHO RMPPL or the PTWI was used for the guideline. In a 1989 WHO document [45], the RMPPL guidelines were shown to be based on the acceptable daily intake (ADI) values. The actual derivation of the WHO RMPPLs is not shown. According to the WHO [45] (p. 10), the ADI was "intend[ed] to provide an indicator of safety for over a lifetime of use", however, the rationale for establishing a PTWI was to demonstrate that metal contaminants "are able to accumulate within the body at a rate and to an extent determined by the level of intake and by the chemical form of the heavy metal present in food. Consequently, the basis on which intake is expressed should be more than the amount corresponding to a single day. Moreover, individual foods may contain above average levels of a heavy metal contaminant, so that consumption of such foods on any particular day greatly enhances that day's intake" [45] (p. 9). Therefore, it was concluded by the WHO that it was appropriate to establish a weekly, rather than daily, tolerable intake. The WHO emphasized that the ADI and PTWI are intended for application to chronic exposure settings, and for ADI, in particular, it is uncommon for exceedances to occur with short-term exposures, which are seen as easily controllable. In both cases, short-lived exceedances are permissible, as long as they do not persist with monitoring.

This study compared the WHO RMPPL to the PTWI and found notable differences between them. To illustrate this point, the literature lists both the dietary intake guidelines, but does not recommend one over the other, nor does one guideline seem to supersede the other $[45,78,79]$. Existing literature, furthermore, does not address conflicting findings, which can cause delay and indecision in developing and utilizing universal guidelines. However, in a more recent publication, the WHO [53] recommends using the PTWI for medicinal plant material metal intake exposures and incorporating the guidelines at the regional and national levels. In the same source, there was no mention or reference to the RMPPL or its status and function. Nevertheless, this may be a first step toward developing universal guidelines. The WHO also discussed the global need to "harmonize" the limits and standards for metals in medicinal plants.

A general literature review reveals a plethora of available dietary guidelines for a suite of metal(loid)s including the WHO RMPPL, the PTWI, the FNB guidelines, and regional and national guidelines for determining metal(loid) contaminants in herbal or medicinal plants. There are differences between the regulations and standards among countries that creates further division and confusion. This was highlighted in the numerous teas studies noted above $[28,33,49,54,74-76,79]$ and demonstrates the need to align or conjoin the guidelines. There is also a need to establish standardized, universally accepted concentration levels for metal(loid)s and to identify, develop, and establish guidelines for absent metals (Cs, Th, and U). Tea is consumed worldwide. As such, its utility and distribution necessitates universal guidelines.

\section{Conclusions}

The concentrations of $\mathrm{Cd}$ in T. megapotamicum tea $(0.35 \mu \mathrm{g} / \mathrm{kg})$ exceeded the WHO RMPPL collectively and in HTAs $(0.68 \mu \mathrm{g} / \mathrm{kg})$. However, calculated human intake did not exceed the RMPPLs set by the WHO or the FNB dietary intake guidelines for $\mathrm{As}, \mathrm{Cd}, \mathrm{Pb}, \mathrm{Mo}$, Se, or V. Similarly, tea sampled from HTAs and LTAs did not exceed the PTWIs or ULs. There was a discrepancy between the WHO RMPPL and the PTWI. However, the PTWI and FNB guideline driven data suggest that the sole consumption of this popular species of tea may not be a dietary risk for metal(loid) ingestion. Again, conflicting and uncertain use of guidelines may be an issue, warranting further development, research, and guidance. As this is a widely used and distributed plant consumed by multiple communities, further research and monitoring are needed to identify factors that affect metal(loid) contamination in T. megapotamicum and other herb and medicinal plants used by the Navajo Nation as well as other $U$ mining impacted global communities. 
Author Contributions: Conceptualization, C.S.-N.; data curation, C.S.-N.; methodology, C.S.-N., F.S.H.; project administration, C.S.-N.; validation, C.S.-N.; formal analysis, C.S.-N.; investigation, C.S.-N.; resources, C.S.-N.; writing-original draft preparation, C.S.-N.; writing—review and editing, C.S.-N., F.S.H.; resources, C.S.-N.; project administration, C.S.-N.; funding acquisition, C.S.-N. All authors have read and agreed to the published version of the manuscript.

Funding: The research reported in this publication was supported by the National Institute of Nursing Research (NINR) of the National Institutes of Health (NIH) under Award Number F31NR013102. The content is solely the responsibility of the authors and does not necessarily represent the official views of the National Institutes of Health. This work was also supported by the NIH/NINR T32NR007077; the University of California, Los Angeles (UCLA), National Institute for Occupational Safety and Health (NIOSH) 2 T42 OH 8412-8, the UCLA Institute of American Cultures (IAC), and the 2011-2013 Navajo Nation.

Acknowledgments: We would like to acknowledge the four participating Diné communities in New Mexico and the Navajo Nation Human Research Review Board (NNHRRB). The assistance of Johnnye Lewis of the University of New Mexico (UNM) Community Environmental Health Program (CEHP), College of Pharmacy, Bob Sivinski of the UNM Herbarium, Chris Shuey of the Southwest Research Information Center (SRIC), and Mehdi Ali and staff at the UNM Analytical Chemistry Laboratory Earth and Planetary Sciences Department are deeply appreciated. We thank Mary-Lynn Brecht and Umme Warda of the University of California, Los Angeles (UCLA) for their statistical assistance.

Conflicts of Interest: The authors declare no conflicts of interest.

\section{References}

1. Hayat, K.; Iqbal, H.; Malik, U.; Bilal, U.; Mushtaq, S. Tea and its consumption: Benefits and risks. Crit. Rev. Food Sci. Nutr. 2015, 55, 939-954. [CrossRef]

2. Korkmaz Görür, F.; Keser, R.; Akçay, N.; Dizman, S.; Okumuşoğlu, N.T. Radionuclides and heavy metals concentrations in Turkish market tea. Food Control 2011, 22, 2065-2070. [CrossRef]

3. Rains, T.M.; Agarwal, S.; Maki, K.C. Antiobesity effects of green tea catechins: A mechanistic review. J. Nutr. Biochem. 2011, 22, 1-7. [CrossRef] [PubMed]

4. Hursel, R.; Viechtbauer, W.; Westerterp-Plantenga, M.S. The effects of green tea on weight loss and weight maintenance: A meta-analysis. Int. J. Obes. (Lond.) 2009, 33, 956-961. [CrossRef] [PubMed]

5. Huxley, R.; Lee, C.M.; Barzi, F.; Timmermeister, L.; Czernichow, S.; Perkovic, V.; Grobbee, D.E.; Batty, D.; Woodward, M. Coffee, decaffeinated coffee, and tea consumption in relation to incident type 2 diabetes mellitus: A systematic review with meta-analysis. Arch. Intern. Med. 2009, 169, 2053-2063. [CrossRef] [PubMed]

6. Jing, Y.; Han, G.; Hu, Y.; Bi, Y.; Li, L.; Zhu, D. Tea consumption and risk of type 2 diabetes: A meta-analysis of cohort studies. J. Gen. Intern. Med. 2009, 24, 557-562. [CrossRef] [PubMed]

7. Kim, A.; Chiu, A.; Barone, M.K.; Avino, D.; Wang, F.; Coleman, C.I.; Phung, O.J. Green tea catechins decrease total and low-density lipoprotein cholesterol: A systematic review and meta-analysis. J. Am. Diet. Assoc. 2011, 111, 1720-1729. [CrossRef] [PubMed]

8. Zheng, X.X.; Xu, Y.L.; Li, S.H.; Liu, X.X.; Hui, R.; Huang, X.H. Green tea intake lowers fasting serum total and LDL cholesterol in adults: A meta-analysis of 14 randomized controlled trials. Am. J. Clin. Nutr. 2011, 94, 601-610. [CrossRef] [PubMed]

9. Carpinel, C.; Ruiz, G.; Palacios, S. Screening of native plants of central Argentina for antifungal activity. Allelopath. J. 2010, 25, 423-432.

10. Figueroa, A.C.; Soria, E.A.; Cantero, J.J.; Sanchez, M.S.; Goleniowski, M.E. Cytotoxic Activity of Thelesperma megapotamicum Organic Fractions against MCF-7 Human Breast Cancer Cell Line. J. Cancer Ther. 2012, 3, 103-109. [CrossRef]

11. Leong, H.; Mathur, P.S.; Greene, G.L. Inhibition of mammary tumorigenesis in the C3(1)/SV40 mouse model by green tea. Breast Cancer Res. Treat. 2008, 107, 359-369. [CrossRef] [PubMed]

12. Shemluck, M. Medicinal and other uses of the Compositae by Indians in the United States and Canada. J. Ethnopharmacol. 1982, 5, 303-358. [CrossRef]

13. Dunmire, W.W.; Tierney, G.D. Wild Plants and Native Peoples of the Four Corners; Museum of New Mexico Press: Santa Fe, NM, USA, 1997.

14. Matthews, W. Navajo names for plants. Am. Nat. 1886, 20, 767-777. [CrossRef] 
15. Adams, C.M.; Bridgforth, E.B.; Dalton, E.; Darby, W.J.; Efner, J.A.; Houk, N.; Johnson, H.F.; McGanity, W.J.; McKinley, P.; Pollard, M.; et al. A study of the dietary background and nutriture of the Navajo Indian. J. Nutr. 1956, 60, 1-85. [CrossRef] [PubMed]

16. Ballew, C.; White, L.L.; Strauss, K.F.; Benson, L.J.; Mendlein, J.M.; Mokdad, A.H. Intake of nutrients and food sources of nutrients among the Navajo: Findings from the Navajo Health and Nutrition Survey. J. Nutr. 1997, 127, 2085S-2093S. [CrossRef] [PubMed]

17. Palacios, S.M.; Maggi, M.E.; Bazan, C.M.; Carpinella, M.C.; Turco, M.; Munoz, A.; Alonso, R.A.; Nunez, C.; Cantero, J.J.; Defago, M.T.; et al. Screening of Argentinian plants for pesticide activity. Fitoterapia 2007, 78, 580-584. [CrossRef]

18. Shaw, D.; Graeme, L.; Pierre, D.; Elizabeth, W.; Kelvin, C. Pharmacovigilance of herbal medicine. J. Ethnopharmacol. 2012, 140, 513-518. [CrossRef]

19. Da Silva Pinto, M. Tea: A new perspective on health benefits. Food Res. Int. 2013, 53, 558-567. [CrossRef]

20. Sarma, H.; Deka, S.; Deka, H.; Saikia, R.R. Accumulation of heavy metals in selected medicinal plants. Rev. Environ. Contam. Toxicol. 2011, 214, 63-86. [CrossRef]

21. Lewis, J.; Hoover, J.; MacKenzie, D. Mining and Environmental Health Disparities in Native American Communities. Curr. Environ. Health Rep. 2017, 4, 130-141. [CrossRef]

22. Samuel-Nakamura, C.; Robbins, W.A.; Hodge, F.S. Uranium and Associated Heavy Metals in Ovis aries in a Mining Impacted Area in Northwestern New Mexico. Int. J. Environ. Res. Public Health 2017, 14, 848. [CrossRef] [PubMed]

23. Samuel-Nakamura, C.; Hodge, F.S.; Valentine, J.L.; Robbins, W.A. Heavy metal contamination in Thelesperma megapotamicum. J. Toxicol. Environ. Health Sci. 2017, 9, 4-22. [CrossRef]

24. Samuel-Nakamura, C.; Hodge, F.S.; Sokolow, S.; Ali, A.S.; Robbins, W.A. Metal(loid)s in Cucurbita pepo in a Uranium Mining Impacted Area in Northwestern New Mexico, USA. Int. J. Environ. Res. Public Health 2019, 16, 2569. [CrossRef] [PubMed]

25. Karak, T.; Bhagat, R.M. Trace elements in tea leaves, made tea and tea infusion: A review. Food Res. Int. 2010, 43, 2234-2252. [CrossRef]

26. DeLemos, J.L.; Bostick, B.C.; Quicksall, A.N.; Landis, J.D.; George, C.C.; Slagowski, N.L.; Rock, T.; Brugge, D.; Lewis, J.; Durant, J.L. Rapid dissolution of soluble uranyl phases in arid, mine-impacted catchments near Church Rock, NM. Environ. Sci. Technol. 2008, 42, 3951-3957. [CrossRef]

27. DeLemos, J.L.; Brugge, D.; Cajero, M.; Downs, M.; Durant, J.L.; George, C.M.; Henio-Adeky, S.; Nez, T.; Manning, T.; Rock, T.; et al. Development of risk maps to minimize uranium exposures in the Navajo Churchrock mining district. Environ. Health 2009, 8, 29. [CrossRef]

28. Arpadjan, S.; Celik, G.; Taskesen, S.; Gucer, S. Arsenic, cadmium and lead in medicinal herbs and their fractionation. Food Chem. Toxicol. 2008, 46, 2871-2875. [CrossRef]

29. Acuna, U.M.; Atha, D.E.; Ma, J.; Nee, M.H.; Kennelly, E.J. Antioxidant capacities of ten edible North American plants. Phytother Res. 2002, 16, 63-65. [CrossRef]

30. Palumbo, M.J.; Talcott, S.T.; Putz, F.E. Ilex Vomitoria Ait. (Yaupon): A Native North American Source of a Caffeinated and Antioxidant-Rich Tea. Econ. Bot. 2009, 63, 130-137. [CrossRef]

31. Kurttio, P.; Harmoinen, A.; Saha, H.; Salonen, L.; Karpas, Z.; Komulainen, H.; Auvinen, A. Kidney toxicity of ingested uranium from drinking water. Am. J. Kidney Dis. 2006, 47, 972-982. [CrossRef]

32. Kirkham, M.B. Cadmium in plants on polluted soils: Effects of soil factors, hyperaccumulation, and amendments. Geoderma 2006, 137, 19-32. [CrossRef]

33. Caldas, E.D.; Machado, L.L. Cadmium, mercury and lead in medicinal herbs in Brazil. Food Chem. Toxicol. 2004, 42, 599-603. [CrossRef] [PubMed]

34. Eisler, R. Arsenic Hazards to Fish, Wildlife, and Invertebrates: A Synoptic Review; Report 12; Biological Report 85(1.12): Laurel, MD, USA, 1988.

35. Van der Ent, A.; Baker, A.J.M.; Reeves, R.D.; Pollard, A.J.; Schat, H. Hyperaccumulators of metal and metalloid trace elements: Facts and fiction. Plant. Soil 2013, 362, 319-334. [CrossRef]

36. Grignard, E.; Gueguen, Y.; Grison, S.; Lobaccaro, J.M.; Gourmelon, P.; Souidi, M. In vivo effects of chronic contamination with 137 cesium on testicular and adrenal steroidogenesis. Arch. Toxicol. 2008, 82, 583-589. [CrossRef] [PubMed] 
37. Meeker, J.D.; Rossano, M.G.; Protas, B.; Diamond, M.P.; Puscheck, E.; Daly, D.; Paneth, N.; Wirth, J.J. Cadmium, lead, and other metals in relation to semen quality: Human evidence for molybdenum as a male reproductive toxicant. Environ. Health Perspect. 2008, 116, 1473-1479. [CrossRef]

38. Meeker, J.D.; Rossano, M.G.; Protas, B.; Padmanahban, V.; Diamond, M.P.; Puscheck, E.; Daly, D.; Paneth, N.; Wirth, J.J. Environmental exposure to metals and male reproductive hormones: Circulating testosterone is inversely associated with blood molybdenum. Fertil. Steril. 2010, 93, 130-140. [CrossRef]

39. Agency for Toxic Substances and Disease Registry (ATSDR). Toxicological Profile for Thorium. U.S. Department of Health and Human Services; Public Health Service, Ed.; CDC: Atlanta, GA, USA, 1990.

40. Agency for Toxic Substances and Disease Registry (ATSDR). Toxicological Profile for Vanadium. U.S. Department of Health and Human Services; Public Health Service, Ed.; CDC: Atlanta, GA, USA, 2012.

41. Western Regional Climate Center. Climatic Historic Summary January 2011-September 2012; Western Regional Climate Center: Reno, NV, USA, 2011.

42. Navajo Nation Division of Natural Resources (NNDNR). Navajo Endangered Species List; Navajo Nation Division of Natural Resources (NNDNR): Window Rock, AZ, USA, 2008.

43. New Mexico Energy, Minerals, and Natural Resources Department (NMEMNRD). New Mexico Rare Plant. Conservation Strategy; Forestry Division, Ed.; New Mexico Energy, Minerals, and Natural Resources Department (NMEMNRD): Santa Fe, NM, USA, 2017.

44. New Mexico Department of Transportation. Functional Classification Guidance Manual; New Mexico Department of Transportation: Santa Fe, NM, USA, 2014.

45. Joint Expert Committee on Food Additives. Evaluation of Certain Food Additives and Contaminants: Thirty-Third Report of the Joint FAO/WHO Expert Committee on Food Additives; WHO: Geneva, Switzerland, 1989; pp. 9-10.

46. Joint Expert Committee on Food Additives. Joint FAO/WHO Expert Committee on food additives. In Proceedings of the Sixty-First Meeting Summary and Conclusions, Rome, Italy, 10-19 June 2003; WHO: Geneva, Switzerland.

47. Salahinejad, M.; Aflaki, F. Toxic and essential mineral elements content of black tea leaves and their tea infusions consumed in Iran. Biol. Trace Elem. Res. 2010, 134, 109-117. [CrossRef]

48. Tsuji, L.J.; Manson, H.; Wainman, B.C.; Vanspronsen, E.P.; Shecapio-Blacksmith, J.; Rabbitskin, T. Identifying potential receptors and routes of contaminant exposure in the traditional territory of the Ouje-Bougoumou Cree: Land use and a geographical information system. Environ. Monit. Assess. 2007, 127, $293-306$. [CrossRef]

49. Han, W.Y.; Zhao, F.J.; Shi, Y.Z.; Ma, L.F.; Ruan, J.Y. Scale and causes of lead contamination in Chinese tea. Environ. Pollut. 2006, 139, 125-132. [CrossRef]

50. Shi, Y.-Z.; Ruan, J.-Y.; Ma, L.-F.; Han, W.-Y.; Wang, F. Accumulation and distribution of arsenic and cadmium by tea plants. J. Zhejiang Univ. Sci. B 2008, 9, 265-270. [CrossRef]

51. Singh, B.R.; Myhr, K. Cadmium uptake by barley as affected by Cd sources and pH levels. Geoderma 1998, 84, 185-194. [CrossRef]

52. Wu, J.; Zou, Y.; Zhan, X.; Chen, S.; Lu, G.; Lai, F. Survey of heavy metal pollution in four chinese crude drugs and their cultivated soils. Bull. Environ. Contam. Toxicol. 2008, 81, 571-573. [CrossRef] [PubMed]

53. World Health Organization. WHO Guidelines for Assessing Quality of Herbal Medicines with Reference to Contaminants and Residues; WHO: Geneva, Switzerland, 2007.

54. Barthwal, J.; Nair, S.; Kakkar, P. Heavy metal accumulation in medicinal plants collected from environmentally different sites. Biomed. Environ. Sci. 2008, 21, 319-324. [CrossRef]

55. Chan, K. Some aspects of toxic contaminants in herbal medicines. Chemosphere 2003, 52, 1361-1371. [CrossRef]

56. Cao, H.; Qiao, L.; Zhang, H.; Chen, J. Exposure and risk assessment for aluminium and heavy metals in Puerh tea. Sci. Total Environ. 2010, 408, 2777-2784. [CrossRef]

57. Chen, Y.; Yu, M.; Xu, J.; Chen, X.; Shi, J. Differentiation of eight tea (Camellia sinensis) cultivars in China by elemental fingerprint of their leaves. J. Sci. Food Agric. 2009, 89, 2350-2355. [CrossRef]

58. Alasalvar, C.; Pelvan, E.; Ozdemir, K.S.; Kocadagli, T.; Mogol, B.A.; Pasli, A.A.; Ozcan, N.; Ozcelik, B.; Gokmen, V. Compositional, nutritional, and functional characteristics of instant teas produced from lowand high-quality black teas. J. Agric. Food Chem. 2013, 61, 7529-7536. [CrossRef]

59. Matsuura, H.; Hokura, A.; Katsuki, F.; Itoh, A.; Haraguchi, H. Multielement determination and speciation of major-to-trace elements in black tea leaves by ICP-AES and ICP-MS with the aid of size exclusion chromatography. Anal. Sci. 2001, 17, 391-398. [CrossRef] 
60. Antal, D.; Dehelean, C.; Dobrea, C.; Manfred, A. Vanadium in medicinal plants: New data on the occurence of an element both essential and toxic to plants and man. Analele Universitatii Din Oradea Fascicola 2009, 16, 5-10.

61. Tokalioglu, S.; Kartal, S. Bioavailability of Soil-Extractable Metals to Tea Plant by BCR Sequential Extraction Procedure. Instrum. Sci. Technol. 2004, 32, 387-400. [CrossRef]

62. Ashraf, W.; Mian, A.A. Levels of selected heavy metals in black tea varieties consumed in Saudi Arabia. Bull. Environ. Contam. Toxicol. 2008, 81, 101-104. [CrossRef] [PubMed]

63. Han, W.Y.; Shi, Y.Z.; Ma, L.F.; Ruan, J.Y.; Zhao, F.J. Effect of liming and seasonal variation on lead concentration of tea plant (Camellia sinensis (L.) O. Kuntze). Chemosphere 2007, 66, 84-90. [CrossRef] [PubMed]

64. Kolachi, N.F.; Kazi, T.G.; Afridi, H.I.; Khan, S.; Wadhwa, S.K.; Shah, A.Q.; Shah, F.; Baig, J.A.; Sirajuddin. Determination of selenium content in aqueous extract of medicinal plants used as herbal supplement for cancer patients. Food Chem. Toxicol. 2010, 48, 3327-3332. [CrossRef] [PubMed]

65. Nookabkaew, S.; Rangkadilok, N.; Satayavivad, J. Determination of trace elements in herbal tea products and their infusions consumed in Thailand. J. Agric. Food Chem. 2006, 54, 6939-6944. [CrossRef] [PubMed]

66. Steenkamp, V.; Grimmer, H.; Semano, M.; Gulumian, M. Antioxidant and genotoxic properties of South African herbal extracts. Mutat. Res. 2005, 581, 35-42. [CrossRef]

67. Ahmed, F.; Daif, M.M.; El-Masry, N.M.; Abo-Elmagd, M. External and internal radiation exposure of herbal plants used in Egypt. Radiat. Eff. Defects Solids 2010, 165, 65-71. [CrossRef]

68. Oprea, E.M.; Pintilie, V.; Bufnea, V.; Aprotosoaie, A.C.; Cioanca, O.; Trifan, A.; Hancianu, M. Radionuclides content in some medicinal plants commonly used in Romania. Farmacia 2014, 62, 658-663.

69. Mitrović, B.M.; Grdović, S.N.; Vitorović, G.S.; Vitorović, D.P.; Pantelić, G.K.; Grubić, G.A. ${ }^{137}$ Cs and ${ }^{40}$ K in some traditional herbal teas collected in the mountain regions of Serbia. Isot. Environ. Heal. Stud. 2014, 50, 538-545. [CrossRef]

70. Stanojkovic-Sebic, A.; Pivic, R.; Josic, D.; Dinić, Z.; Stanojković, A. Heavy metals content in selected medicinal plants commonly used as components for herbal formulations. Tarim Bilim. Derg. 2015, 21, 317-325. [CrossRef]

71. World Health Organization. Quality Control. Methods for Medicinal Plant. Materials; WHO: Geneva, Switzerland, 1998.

72. Blagojevic, N.; Vratnica, B.; Vukasinovic-Pesic, V.; Djurovic, D. Heavy Metals Content in Leaves and Extracts of Wild-Growing Salvia Officinalis from Montenegro. Pol. J. Environ. Stud. 2009, 18, 167-173.

73. Apeagyei, E.; Bank, M.S.; Spengler, J.D. Distribution of heavy metals in road dust along an urban-rural gradient in Massachusetts. Atmos. Environ. 2011, 45, 2310-2323. [CrossRef]

74. Naithani, V.; Kakkar, P. Effect of ecological variation on heavy metal content of some medicinal plants used as herbal tea ingredients in India. Bull. Environ. Contam. Toxicol. 2006, 76, 285-292. [CrossRef] [PubMed]

75. Naithani, V.; Kakkar, P. Evaluation of Heavy Metals in Indian Herbal Teas. Bull. Environ. Contam. Toxicol. 2005, 75, 197-203. [CrossRef] [PubMed]

76. Yuan, C.; Gao, E.; He, B.; Jiang, G. Arsenic species and leaching characters in tea (Camellia sinensis). Food Chem. Toxicol. 2007, 45, 2381-2389. [CrossRef]

77. Food and Nutrition Board. Dietary Reference Intakes for Vitamin A, Vitamin K, Arsenic, Boron, Chromium, Copper, Iodine, Iron, Manganese, Molybdenum, Nickel, Silicon, Vanadium, and Zinc; The National Academy Press: Washington, DC, USA, 2001.

78. Gil, F.; Hernández, A.F.; Martín-Domingo, M.C. Chapter 58-Toxic Contamination of Nutraceuticals and Food Ingredients. In Nutraceuticals; Gupta, R.C., Ed.; Academic Press: Boston, MA, USA, 2016; pp. 825-837. [CrossRef]

79. Kosalec, I.; Cvek, J.; Tomic, S. Contaminants of medicinal herbs and herbal products. Arhiv Hig. Rada Toksikol. 2009, 60, 485-501. [CrossRef]

(C) 2019 by the authors. Licensee MDPI, Basel, Switzerland. This article is an open access article distributed under the terms and conditions of the Creative Commons Attribution (CC BY) license (http://creativecommons.org/licenses/by/4.0/). 